\title{
Gendered Narratives of Illness and Healing: Experiences of Spirit Possession in a Charismatic Church Community in Tanzania
}

\author{
Lotta Gammelin
}

Church services at the Gospel Miracle Church for All People (GMCL) ${ }^{1}$ follow a dramatic pattern that is always very similar: the culmination point comes after the sermon and offering with the healing session in which women lost in spirit trances become the focus of the congregation's attention. Usually they scream, resist, and try to escape, and several people are required to hold them down and still during the loud and vivid intercession prayers and laying on of hands. As the prayers commence, and Prophet Mpanji, leader and founder of this community, encourages people to join him in prayer and spiritual warfare (vita vya kiroho), female choir members and pastors wrap large pieces of cloth around their waists to protect their clothing. It is a practical act, since healing prayers are physical and messy. The patients roll around on the mud floor and as the holy water is thrown on them sludge builds up that covers their clothes and bodies and also spatters the prayer servants for whom assisting in the healing session is physically demanding. Dressing for a prayer session is also a strongly symbolic action: they are entering a war on behalf of their sisters who are forced to live with malicious spirits and long for redemption. Meanwhile the congregation is invited to join communal prayer for the spirit possessed, as well as being urged to destroy evil forces in their own lives. More than that, they are also spectators whose fascination for the on-going drama is obvious and who watch events with fervent intensity. When spirit possession becomes public it invites "contemplation, interrogation, identification, and edification for those around them", as Lambek writes. ${ }^{2}$

1 Empirical data for this chapter was gathered during a total of eight months of fieldwork in Mbeya in 2013 and 2014. I choose to use the abbreviation GMCL as it is used by the community in question. All the names of the informants are pseudonyms apart from Prophet Mpanji's.

2 Michael Lambek, "Rheumatic irony: Questions of agency and self-deception as refracted through the art of living with spirits," Social Analysis 47, no. 2 (2003): 41. 


\section{Introduction}

The GMCL is a locally founded church community situated in the city of Mbeya, Southern Tanzania, in the vicinity of the Zambia-Malawi border. The GMCL has, during its decade-long existence, grown from a small prayer group meeting in a private home into an established and locally well-known Christian community that attracts around 500 adults to its Sunday services. Healing prayers that concentrate on driving away spirits are part of every worship service and are, for many believers, the main reason for joining this community. This chapter is based on interviews conducted with female members of the GMCL, and their narratives of falling ill and healing; it examines spirit possession that takes place in a Charismatic Christian community by paying attention, not primarily to the spirit trance, but to the ways in which people who live with spirit possession describe and explain their lives.

The general discourse on illness in the GMCL is strikingly gendered; in healing sessions almost all the sick, or wagonjwa as they are called by the community, who experience spirit trances are mostly women in their reproductive years, although little girls and older women were also prayed over on occasion. During more than eight months of fieldwork I only saw a few exceptions to this rule when teenage boys and older men were spirit possessed and dragged to the front. Is it the case that masculinity provides protection from the attacks of the spirit world whereas femininity makes one vulnerable? Certainly, as this chapter discusses, possession and its healing seem to have a strong link to fertility, sexuality, and reproduction - not that there is anything unique about spirit possession as a gendered phenomenon; on the contrary, most spirit possession cases reported in research are in some way gender specific. ${ }^{3}$ It is a shared belief in the GMCL that men can also be harmed by the spirits and made ill by them; their illness, however, seems to follow a different pattern that lacks the aspect of trance: the unconscious state of being taken over by the spirits. Furthermore, men's involvement with the spirits seems to be less connected with sexuality. For women who seek help from the GMCL, sexuality is strongly present in their narratives of how they perceive their illness, healing, and spirit interference in their daily lives. These stories illustrate how illness and gender are intertwined in this community: How do women explain their

3 David Gordon, Invisible Agents. Spirits in Central African History (Ohio: University Press, 2012) Kindle Edition, loc 401; Janice Boddy, "Spirit possession revisited. Beyond Instrumentality," Annual Review of Anthropology, 23 (1994): 407-434; Heike Behrend and Ute Luigi, "Introduction," in Spirit Possession. Modernity \& Power in Africa (Madison: University of Wisconsin Press, 1999), xiii-xxii. 
experiences of falling ill due to interaction with the spirit world? What is the nature of the discourse on sexuality, agency, and gender roles in society that is being created by these stories?

All the interviews I conducted with lay Christians and female pastors ${ }^{4}$ contained a common theme: when I asked to hear their life stories I was told a narrative of falling ill and being attacked by the spirits. I was expecting this of some of the research participants, since a number lived in the church premises because of their problems; these were the congregation members generally referred to as wagonjwa, although their medical conditions varied. Some stayed there for weeks, some for months, and some more than a year. Reasons for this could be largely practical - the homes of some were far away in the province or in another region and they had no relatives in Mbeya to host them - but some chose to stay in the church because they felt safer there. At home, they said, the spirits' attacks were more severe. At the church there was always someone to pray for them, and frequent morning, evening, and afternoon prayers were conducted with the church dwellers. ${ }^{5}$ Yet I found it surprising and noteworthy that all the women I interviewed, whether they were lay Christians, choir members, or pastors, told a story of falling ill, being afflicted, and finally regaining well being at the church. Most recounted a personal journey, while some were looking for help for their children, but for all of them the reason for coming to the GMCL was illness, and the church was a place of healing. Selecting this particular church was thus not only a choice of place of worship but also a health-seeking decision, which was often the result of searching for help from various other places before turning to Prophet Mpanji. ${ }^{6}$

Maybe due to its glaring otherness to the outsider encountering it, spirit possession has attracted immense scholarly interest and accumulated a lot of theorizing. In the past, possession was sometimes seen as a separate and discrete sphere of life, but it is now widely accepted that possession also speaks of and to other fields in the societies in which it takes place. This notion has directed research examining different forms of possession towards more contextualizing tendencies that view it in relation to the wider historical and social framework. As Janice Boddy has argued, spirit possession is more than just the

4 Pastors in the GMCL were lay pastors in the sense that they had no paid positions but had their livelihoods from elsewhere. They were called to duty by Prophet Mpanji according to his visions.

5 Interview with Faraja, July 18th 2013. During my fieldwork the number living in the church fluctuated between 20 and 35 . I was told that the group had been bigger in previous years, with more than 100 residents.

6 See Lotta Gammelin, "Health-seeking nomads and faith-healing in a medically pluralistic context in Mbeya, Tanzania." Mission Studies. Volume 35. (2018) 245-264. 
dramatic acts visible and audible in rituals, but rather something that is encountered and lived with in everyday life. It has to do "with one's relationship with the world, with selfhood - personal, ethnic, political, and moral identity."

As a theologian exploring lived Christianity I build theoretically on previous anthropological research into spirit possession, especially that of scholars who examine it in relation to agency and morality. Michael Lambek's extensive study of "lives lived with possession" in Mayotte, for instance, has helped to move studies on spirit possession from an instrumentalist orientation towards a more meaning-oriented approach. ${ }^{8}$ Lambek views spirit possession in relation to the social world as a means of communication by which messages are conveyed between people in a specific cultural setting. He also makes a necessary distinction between persons who are directly possessed and persons through whom a spirit acts. In the case of the latter the experiencing of a spirit is "distanced and objectified sufficiently to be available for ... others in form of a narrative." This is also true of my research participants. Apart from spirit trance, which seems to be an unconscious state that leaves no active memory on the part of the spirit medium, interviewees were able to talk about their relationships with the spirits, producing consistent, detailed narratives that unfold in various directions. As Janice Boddy points out, spirit possession is almost always about morality, hence relationships with the past, ${ }^{10}$ and at the GMCL the spirits attacking human beings are often associated with ancestors, meaning that possession in this context specifically engages with what is seen as the past.

It was not difficult for me to take seriously the stories of my research participants as they shared what were clearly extremely painful experiences, and yet, in many situations, especially when the state of spirit trance was publicly displayed, I found myself pondering its obviously socially created character. Instances of trance took place and intensified at the end of church services, for example, when there was appointed space for them and time for the healing session. The stories I heard and the dramatic nature of the trances made me ask myself a question that is doomed to remain unanswered: What really happens when people are spirit possessed? Ethnographic fieldwork is always a meeting point between different worldviews, and the researcher's own ontological perspective becomes especially visible in encounters with radical

7 Boddy, "Spirit possession," 414.

8 See Michael Lambek, Knowledge and Practice in Mayotte: Local Discourses of Islam, Sorcery, and Spirit Possession (Toronto: University of Toronto Press, 1993); Boddy, "Spirit possession," 408, 410.

9 Lambek, "Rheumatic irony," 54.

10 Boddy, "Spirit possession," 414, 422. 
otherness, as spirit possession was for me. I found myself wondering, like many researchers before me, if spirit possession might be a local expression of something with a Western equivalent in psychiatric diagnoses. Or is it a local cultural category - in Boddy's terms a "metacultural"11 production - that should be met on its own terms, without attempts to translate it into something intelligible to the outsider's mind?12 Addressing the question "what really happens?" is both tricky and irresolvable yet, in my opinion, necessary, as it lays open epistemological differences that are at work in ethnographic research: ethnography, as I see it, happens when the researcher allows her own confusion and at times even discomfort to meet with the local understandings without claiming to know better or discrediting the local narratives. Spirit possession is, as Boddy argues, a story that its participants tell themselves, about "themselves and others", ${ }^{13}$ although not in a sense that suggests inauthenticity. Lambek writes about this conflict in the following terms:

Spirit possession is simultaneously a part of life, something that really happens, that hurts, harms, or heals and establishes relationships, and an artistic production and performance, a lens of drama through which life is inspected, highlighted, reshaped, reflected upon, and responded to. ${ }^{14}$

I argue that our analyses of encounters with the spirits can only be accountable when they accept, value, and remain open to epistemic premises different from those the researcher possesses. The experiences of people living with the spirits must be taken seriously while also looking for alternative meanings and explanations.

Symptoms of spirit involvement varied among my research participants. Some told me of headaches, dizziness, fainting, and being unable to work, which in effect caused economic problems and an inability to look after one's family. Some started to see blood where other people saw water. Abdominal pains are a general symptom, which were often associated with the womb. Some reported experiences of struggling because their personality was taken over by someone else; some were driven to the brink of suicide or murder. In the stories

\footnotetext{
11 Boddy, Wombs and Alien Spirits, 9

12 Boddy, "Spirit possession," 407-413.

13 Boddy, Wombs and Alien Spirits, 9.

14 Lambek, "Rheumatic irony," 53.
} 
I was told spirit involvement generally brought chaos to the lives of its victims, decreased their intelligence, and destroyed their capacity to strive in life. It complicated relationships and made its victims vulnerable. Yet, although there is great variety in the symptoms and different hardships caused by the spirits, there are also numerous similarities. Since stories are shared with others publicly in church services, and Prophet Mpanji also includes anecdotes of spirit possession in his sermons, there are inevitably certain similarities in the narratives of spirit attack. Furthermore, individual stories of falling ill are reflected on and further developed as ideas in relation to other, similar experiences. ${ }^{15}$

My research participants were not necessarily very specific about the actual spirits that possessed them, although some spirits were known by name and there were distinctions and a sort of hierarchy between different types of spirits. ${ }^{16}$ The terms pepo and jini could both be translated as spirits, but majini (pl.) were generally seen as stronger and more disturbing than mapepo (pl.). ${ }^{17} \mathrm{Nuru}$, who herself had been troubled by different kind of spirits, explained the difference:

Jini is greater than pepo. It is possible you meet a person and you are told this person Nuru has jini. And maybe Mary has pepo, so the war of Mary and the war of Nuru must be different. I would say, mostly pepo is sent to torture a person, but when jini comes to a person, mostly it is to kill her straight away. ${ }^{18}$

15 Päivi Hasu has presented a similar notion in her analysis of the Glory of Christ Tanzania Church located in Dar es Salaam in relation to publicly shared zombie narratives. Päivi Hasu, "The Witch, the Zombie and the Power of Jesus: A Trinity of Spiritual Warfare in Tanzanian Pentecostalism," Suomen Antropologi/Antropologi I Finland/The Journal of the Finnish Anthropological Society 34, no. 1 (2009): 75 .

16 In the letters addressed to Emmanuel Milingo, at the time Roman Catholic Archbishop of Lusaka, in the 1970s by people asking for his prayers exhibit a similar lack of specificity in naming the spirits. In her analysis of the letters Gerrie ter Haar points out that the distinctive local categories that previously existed in Zambia concerning different spirits have eroded and Zambians who wrote to Milingo were referring to one category only: evil spirits which ter Haar sees as process where local spirits are incorporated into a universal religion. Gerrie ter Haar, Spirit of Africa: The Healing Ministry of Archbishop Milingo of Zambia. (London: Hurst, 1992): 108-113.

17 Jini is sometimes suggested as having its origins in Islamic understanding of spirits as the word derives from Arabic but I never heard this explanation in Mbeya. See Kjersti Larsen, "Morality and the Rejection of Spirits. A Zanzibari Case," Social Anthropology 6, no. 1 (1998): 61-75.

18 Interview with Nuru, February 3 rd 2014. “...jini ni kitu kikubwa kuzidi pepo, yaani unaweza ukakuta mtu unaambiwa kwamba huyu, huyu Nuru ana jini. Huyu, labda huyu Mary ana pepo yaani vita ya Mary na Nuru lazima iwe tofauti. Yaanijini sijui niseme mara nyingi sana 
Nuru further explained that not only do different spirits work in different ways, but every person is also tested and affected in different ways. ${ }^{19}$ Spirits are sometimes identified according to their effects, such as pepo la ulevi (spirit of drunkenness) that causes alcoholism, pepo la uzinzi (spirit of adultery) that makes one indulge in adultery or other sexually immoral behavior, pepo la kiburi (spirit of arrogance) that brings conceit. ${ }^{20}$ Spirit possession is not an emic term, however, and my research participants did not use it. When speaking of their interactions with the spirits they used Kiswahili words for being abducted (kutekwa), disturbed (kusumbuliwa), made ill (kuumwa), or being attacked (kuvamiwa) by the spirits; many also spoke of spirits that inhabit (kukaa) a person.

My research participants often associated spirits with ancestors, usually female. Some spirit possessed women told me they were haunted by late relatives who wanted to influence their lives even after death, with deceased females especially interested in their descendants' ability to conceive. Some spoke explicitly about witchcraft (uchawi) as the source of their problems, and most were able to name some contemporary member of their community who aimed to harm them or profit at their expense by manipulating the spirits. There was, however, an element of speculation and uncertainty, even reluctance, when naming the person or persons causing these problems, and none of the women I interviewed had any desire to confront these people as prayer was seen as sufficient defense. As Nuru said, spirits seem to be sent by someone; they are agents, not acting on their own but assigned a mission. ${ }^{21}$

In the context of Charismatic Christianity the spirits are identified as malevolent representatives of the pre-Christian past and are seen as a threat to Christian faith. I was told by my research participants that the spirits are very attracted by born-again Christians and make them particular targets of attack, thereby putting faith to the test. Pentecostal interpretation of the ancestral spirits often demonizes them as unequivocally bad, whereas traditionally the ancestral spirits were seen as ambivalent, bringing good, bad, and in-between. ${ }^{22}$

pepo anapotumwa kwa mtu kumtesa. Jini linapokuja kwa mtu mara nyingi ni la kuua moja kwa moja."

19 Interview with Nuru, February 3rd 2014.

20 Interview with Pastor Lusungu and his wife Susan, July 16th 2013.

21 Although Nuru referred here to jini, people in Mbeya talked about both mapepo and majini as agents that could be sent by someone.

22 Birgit Meyer, "Make a Complete Break With the Past.' Memory and Post-Colonial Modernity in Ghanaian Pentecostalist Discourse," Journal of Religion in Africa 28, no. 3 (1998): 316-349. 


\section{Occupied Wombs}

Many of my female informants told me about sexual relations - either forced or voluntary - with the spirits. The spirits are gendered and some spirits form relationships of a sexual nature with the people they possess. One of them is Sofia, at the time of our interview a thirty-year-old woman who was born and raised in Mbeya. Sofia came to the GMCL after years of struggle. Her problems started when she met a boy at school and got pregnant at the age of sixteen. Due to her pregnancy Sofia had to drop out of school and they started life together as husband and wife. ${ }^{23}$ The boy's parents opposed this as they wanted their son to continue his education, but the young couple was persistent and he also left school. Sofia, however, lost her baby before the child was born. They then moved to Dar es Salaam where they lived together for two years during which time Sofia's condition was devastating: she was exhausted, kept fainting, and was haunted by a strong, unpleasant perfume. Then she got pregnant again. By this time her father had forgiven her and she travelled home to him, leaving her boyfriend behind, but when he discovered her pregnancy he was furious and sent her away to stay with her boyfriend's parents. Sofia was in her eighth month and had two weeks left before her due date when one night she awoke to a sharp and sudden pain in her belly. Sofia's father heard about this and sent her to the hospital where the doctor examined her. The baby had oddly disappeared from her womb. The doctor said that the signs of pregnancy were there but the baby was lost, and there was no medical explanation for this. After these dramatic events Sofia's father enrolled her in a private secondary school for a fresh start but, as he died later that year, Sofia had to drop out of school again for there was no one to pay the fees. After losing her father and the baby Sofia's condition started to worsen. She often fainted, but also started to wake up in graveyards in a terrible condition after going to sleep at home, although in Tanzania graveyards are avoided as dubious places apart from funeral attendance. "Going to the graves" is a euphemism for ancestral veneration, a practice associated with pre-Christian religious practice, and in urban settings witch accusations and rumor often contain stories of graveyards. Sofia also found chale (cuts) on her wrists, arms, and stomach, with no idea of their origin. ${ }^{24}$ She tried to work in a stationery shop, but its owner could not put up with her unpredictable condition. Every night the spirits took her to kuzimu, the underworld, a place ruled by satanic forces. Sofia could still remember how

23 Co-habiting without officiated marriage is common in Tanzania.

24 Many traditional healers also make chale, ritual cuts that are part of therapeutic processes. 
it was and described it to me in obvious agony. She had seen people who were forced to work without any rest. Enslaved, they were forced to act against their own will. I asked Sofia if she was forced to work, too. "Yes," she replied, "I was forced to give birth and to breastfeed those babies. They were majini, spirits."25

When I asked Sofia whether she knew the source of the difficulties she had to face she answered that her problems were caused by her former boyfriend's family. They wanted to use her star, nyota, for their own benefit. Nyota was mentioned in many stories I heard. All human beings are born with a star that is part of their personality, containing their abilities and the personal qualities that enable success, which can be stolen and exploited through witchcraft. After prayers over Sofia began at the GMCL her former boyfriend was committed to mental hospital and his father, who had been harsh to Sofia and made her work very hard in their household, had a stroke. Without claiming that that revenge was inflicted upon them through prayer, she explained that it happened because of the prayers. Since coming to the church in 2010 in search of healing Sofia has been much better. She does not wake up in graveyards, she does not have bleeding wounds on her arms and wrists, and she is no longer taken to kuzimu at night to give birth. Sofia met her husband at the GMCL and they have a nice home; however, despite the prayers and getting much better, the spirits still trouble her and she is not able to get pregnant, although a medical doctor has not found any physical reason for this. According to Sofia it is because her late mother stops her from conceiving. Sofia believes that her mother, who passed away years ago, is trying to persuade her to become a mganga, a traditional healer, like her grandfather was. "She disturbs me; I think she wants me to do the work her father did. For me not to lose their tradition," Sofia said. ${ }^{26}$ But Sofia refuses to become a mganga, and her mother continues to trouble her. ${ }^{27}$

The theme of breaking with the past is not only present in the lives of Charismatic Christians in Tanzania; all Christian traditions deal with it in one way or another. ${ }^{28}$ In Sofia's story the conflict with the past that in many ways reaches into her present life is a feature of her late mother's insistence on her becoming a mganga, indicating that what is often referred to as "the past" is actually the present: powerful, tangible, and playing a role in the here and now. In Sofia's case it has brought anguish and loss through control over her fertility.

25 Interview with Sofia, January 17 th 2014.

26 "Ananisumbua, nafikiri anataka nifanye kazi labda aliyokuwa akifanya baba yake, nisipoteze asiliyao." Interview with Sofia, January 17 th 2014.

27 Interview with Sofia, January 17th 2014. Traditional healing is often passed on in a family.

28 Meyer, "Make a Complete Break." 
Since biomedical examinations have not shown any medical reason for infertility, the past seems to have power over the biological facts. The unsuccessful visits to traditional healers and biomedical healthcare practitioners that reoccur in many of these narratives seem to testify to prayer as the only viable instrument for removing the spirits. Biomedical care seems to be especially helpless in the face of spirits, whereas prayer penetrates the spirits' realm and has power to manipulate the otherworldly powers.

As already noted, grandmothers or female relatives frequently play a part in spirit possession stories. They are portrayed as bringing misfortune and miscarriage, preventing conception, and disturbing marriage plans. ${ }^{29} \mathrm{I}$ argue that this hostile representation of older women has to do with two things: first of all, there is certain amount of contradiction in attitudes towards elderly women in general in Tanzania. They are valued and respected for their life experience and wisdom, but the theme of old women as witches is also prevalent in the popular imaginary. In some areas of Tanzania witchhunts and accusations against older women have in recent years have caused attacks on and even the murders of alleged witches. ${ }^{30}$ Because of their age, they are excluded from the reproductive tasks of the society at many levels: they cannot participate in work like the young and they no longer give birth. It is suspected that, as a result, they envy younger women who are vital to the society for their reproductive capacity. In popular witchcraft discourses the witch is someone who is excluded from society and his or her actions are often motivated by envy. ${ }^{31}$ The second reason why grandmothers reoccur in these stories could be that old women are seen as a link to traditional practices which are, of course, a much needed enemy ex officio for the Christian narrative. In Sofia's story her mother wanted her to maintain family traditions by becoming a traditional healer, a demand Sofia saw as contradicting her Christian faith.

The ways that sexuality and fertility are discussed through the medium of spirit possession are also exemplified in Hekima's life story. Hekima and her

29 In her work among the Sukuma-Nyamwezi, Hinkkanen suggests the same notion, especially with regards matrilinear ancestors. For the Sukuma infertility can be caused by a powerful female ancestor from matrilineal side who has been infertile herself. In my fieldwork I did not encounter this passing on of infertility. Reea Hinkkanen, "Someone to welcome you home." Infertility, medicines and the Sukuma-Nyamwezi, (Helsinki, Reea Hinkkanen, 2009), 75-76.

30 Edward Miguel, "Poverty and witch killings," Review of Economic Studies 72 (2005): $1153^{-1172 .}$

31 Mark Auslander, "Open the Wombs!" Symbolic Politics of Modern Ngoni Witchfinding, "in Modernity and Its Malcontents. Ritual and Power in Postcolonial Africa, eds. Comaroff \& Comaroff (London, Chicago: University of Chicago Press, 1993), 178-179. 
husband were married for almost five years before their first child was born. The problems started after that. Hekima lost interest in making love with her husband, which created discord in her marriage. She felt no pleasure with him but, rather, avoided intimate contact. During her sleep, however, she was frequently visited by a lover with whom she enjoyed having sex. This lover looked like a man, but in reality was a spirit (pepo). Hekima said she did not even know she was troubled by the spirits, when in fact she was married to them. Another problem started when she weaned her baby. Although the infant no longer needed her milk, lactation did not end and milk continued to flow in a disturbing way. Later on it was explained to her that the breast milk was for feeding the babies she was having in kuzimu, a place that is ruled by the nguvu za giza (the forces of darkness) where the spirits reside. She was troubled for years and sought help from biomedical healthcare. After meeting various doctors she even went to Muhimbili hospital in Dar es Salaam, meanwhile attending a Christian ministry in Mbeya where she was prayed for again and again, to no avail. ${ }^{32}$ Finally, when Hekima was in the process of making an expensive trip to India for a medical operation that would stop lactation, she heard about Prophet Mpanji and decided to give his church a try. She attended prayers for several months, both during the service and performed individually by the prophet, which reduced lactation to a tolerable level while her headaches, exhaustion, and marital problems came to an end. She is still awaiting another pregnancy - in God's time. "It was not my expectation to have one child. I assumed I would have three children. But I am waiting for God to give me other children."33

Sofia's and Hekima's stories of being used sexually by the spirits are not unique. Many research participants told me about similar experiences, and marriage with the spirits (ndoa na majini) was fought against in communal prayer during the services. ${ }^{34}$ Some research participants were forced into sexual intercourse with the spirits; for others, like Hekima, it was at first a pleasure

$32 \quad$ Interview with Hekima, April 3oth 2013.

33 "Si matarajio yangu kuwa na mtoto mmoja. Nilitegemea niwe na watoto watatu. Lakini ninamsubiri Mungu anipe watoto wengine." Interview with Hekima, April 3oth 2013.

34 Marriage with the spirits is a common trope found in possession narratives in different regions of Africa, both in Christian contexts and other possession cults. See for instance Paul Gifford, Christianity, Development and Modernity in Africa (London: Hurst and Company, 2015), 21-23. In her research among Brazilian Pentecostal churches in Mozambique Linda van de Kamp analyses case of spirit spouses. Van de Kamp sees conversion to Pentecostalism as a strategy for controlling one's body and sexuality. Linda Van de Kamp, "Converting the Spirit Spouse: The Violent Transformation of the Pentecostal Female Body in Maputo, Mozambique," Ethnos:Journal of Anthropology 76, no. 4 (2011): 510-533. 
but later proved to be a source of problems. The spirit lover (jini mahaba) was often the last of the problems to remain when prayers had already started to alleviate other troubles. Like Sofia and Hekima, others also told me about being forced to give birth to children who were actually not children, but evil spirits. This was especially painful if the person was childless and unable to conceive real children; being mzazi, a birthgiver in kuzimu, was seen as a reason for infertility because one's womb was already taken, occupied by the spirit babies.

In the Tanzanian context children are highly valued and infertility is seen as a tragic condition. Family planning is usual, however, especially in urban and semi-urban contexts like Mbeya, and having a very large family can be seen as backwardness and irresponsible behavior in the face of harsh economic realities; while children were previously considered an economic asset they are nowadays seen as a source of expenditure. Yet the availability of contraception, and education encouraging smaller families, have not erased the widely shared notion of children as a blessing and social capital. Infertility, whether primary or secondary (the inability to carry pregnancy to term following the birth of one child, as in Hekima's case), is generally seen as a bigger problem for women than for men - even a source of social stigma. Becoming a mother in Tanzania makes a woman a person of social relevance, and it is the woman who undergoes medical examinations to seek a solution to the problem; the husband is not necessarily tested for infertility at all, and thus blame stays with the wife. ${ }^{35}$ Infertility, as my research participants explained it to me, seems to be the least desired position one could imagine for anyone, and thus a very popular motif in witchcraft narratives fuelled by revenge and envy. Infertility as a female problem was also clearly demonstrated in the church services, as many times during his vivid sermons Prophet Mpanji asked if there was anyone present who was there in search of a child ("Nani anatafuta mtoto?" Who is searching for a child?) and dozens of women would raise a hand or, in the case of eager longing, both hands. I never saw men publicly demonstrate their wish for a child in the same way, although I do not claim this to indicate that fertility and offspring were not of paramount importance to both men and women. Nonetheless, it seems that this concern is assigned to women in public life and that the concern over motherhood and reproduction actually produces a gendered sense of self.

35 Hinkkanen, "Someone to welcome," 54-56; Auli Vähäkangas, Christian Couples Coping with Childlessness. Narratives of Machame, Kilimanjaro, American Society of Missiology Monograph Series. (Eugene, Oregon: Pickwick Publications, 2009). 
Once, during a worship service, Prophet Mpanji invited a woman to the front with her toddler son, and interviewed her. She had to describe the biomedical examinations she underwent because of her childlessness, but there was no mention of her husband going through similar procedures. The medical doctor had examined her and discovered that her fallopian tubes were not functioning, and due to this it was biologically impossible for her to conceive. Despite the hopeless prognosis she came to Mpanji for prayers and now stood in front of the congregation holding her toddler son who was named David after the prophet, for he had made the impossible possible. Mpanji was visibly very pleased as he asked the name of the child. In many pre-colonial societies it was the responsibility of the king or chief to ensure fertility of his subjects. ${ }^{36}$ Thus, by praying for fertility and giving space for concerns over reproduction, Mpanji embodies the idea of a leader who enables fertility and thus touches the core values of society.

The relationship between sexuality and supernatural forces is well documented in ethnographies of various African societies. The example that is geographically closest to Mbeya is provided by Monica Wilson's work on the Nyakyusa. The Nyakyusa are not native to Mbeya city, but their homeland is in close proximity, in the surrounding countryside and neighboring towns, and many of them live in Mbeya city nowadays. In traditional Nyakyusa perception, as documented by Wilson, ancestral spirits can prevent sexual intercourse from being fruitful and are thus seen to be an element of sexual relations between living human beings. ${ }^{37}$ I find it interesting that these accounts of sex with the spirits create a space in which to talk about women's sexual desire, which is generally not discussed, at least not publicly. At the same time sexuality in these encounters with the spirits is mainly seen in relation to fertility and reproduction, and is actually portrayed as dangerous. This discourse links sex with illness, destruction, and leading an unsatisfactory life. Apparently, these stories of illness are about control over sexuality and fertility, combined with warnings about extramarital sex. Public discourses on sexuality in East Africa are often fundamentally linked with either reproduction or HIV/AIDS and the moral panic that comes with them. The way sexuality is presented in the narratives of illness told by my informants seems to reflect and reproduce similar values: sex is intended for marriage only and especially for creating offspring,

$36 \quad$ Märta Salokoski, How kings are made, how kingship changes. A study of rituals and ritual change in pre-colonial and colonial Owamboland (Helsinki: Helsinki University Press, 2006), 17-19; Gordon, Invisible Agents, loc. 10102-10103.

37 Monica Wilson, Rituals of kinship among the Nyakyusa. (London, New York: Oxford University Press, 1957), 55 . 
while extramarital relationships, even with the spirits, cause trouble. Given the religious tradition of this area, obsession with the womb and ensuring fertility is not a surprising feature in local Christian discourse. In pre-colonial religious and political thought control over fertility and reproduction was a religious matter and there was a shared understanding of its connection with the ultimate powers. The link between sex and the sacred is strong. ${ }^{38}$

As my research participants narrate their lives with the spirits they often implicitly speak of the loss of subjecthood and agency. The spirits cause them to lose their abilities and stop them from achieving something they desire. By agency I simply mean the capacity to act, to make life choices and to some extent be in control of one's life. Nuru explains how she felt when her troubles begun:

I felt really bad, because all my things stopped at that point. Because of my condition I changed; I started to go out of my mind. I was unable to do any work, because at the time I had a rice business. It could happen that I was at the machine husking the rice and suddenly it [the spirit] became like a person standing in front of me. That meant my business has stopped. I have not gone back to it again since I started to suffer from this condition. I have not done business since then. Even if I said I did business, it was not successful; it was ruined. Even if I do business, I sell, I see no profit. ${ }^{39}$

Like Nuru, many others explain their troubles not only as physical pain but also as the end of active life, and often loss of livelihood as well. The loss of agency due to a spirit's involvement is exemplified in Asifiwe's story. Asifiwe's mother knew God and although she was illiterate she loved the Bible and

38 Gordon, Invisible agents, loc. 412-417.

39 Interview with Nuru February 3rd, 2014. "Nilijisikia vibaya sana kwa sababu kwanza kila kitu changu kimesimama. Kwa hiyo ile hali pale pale nabadilika naanza kuchanganyikiwa. Yaani nilikuwa nashindwa kufanya kazi yoyote, sababu unaweza ukakuta mimi nilikuwa nafanya biashara ya mchele. Naweza nikawa niko mashineni nakoboa ghafla anakuja kama mtu anasimama mbele yangu. Ina maana biashara zangu zilisimama na toka pale sijawahi kufanya biashara tena toka nilipoanza kuhangaika na ile hali, sikuwahi kufanya biashara tena. Halafu hata kama nilisema nifanye biashara haiendi, inaharibika yaani kwamba naweza nikafanya biashara nauza, sioni faida." 
always bought her children books that had pictures of Jesus. Asifiwe and her siblings attended Sunday School and church and she was born-again at a school revival in the Moravian church when she was in fourth grade at primary school. From then on she led the life of a born-again girl: she went to school, acquired a fiancée, and married and moved to Mbeya city from the nearby countryside. They were married for nine years but Asifiwe did not get pregnant and childlessness became more painful as the years passed. Asifiwe started to ask God: "Why is it that I do not succeed in life although I know God? Why is my life like this?"40 In 2010 they heard about Prophet Mpanji and went to see him. At the time Asifiwe's husband was also ill. Asifiwe herself was in a poor state; her face had changed and her body was altered. Prophet Mpanji asked them questions, and then he explained the root of their problems: the spirits had taken over Asifiwe. Despite prayers for his health, Asifiwe's husband died six months later. She was left alone but continued to go to Mpanji. Just before his death Asifiwe's husband had also encouraged her to continue attending the prayers, saying, "You are not yourself." ${ }^{11}$ The prophet had told her that God would release her, which puzzled Asifiwe as she was already born-again.

Prophet Mpanji gave her a package of salt and told her to go home with it. Asifiwe was surprised but followed the prophet's instructions to use it normally while cooking. The night after she started to use the salt, she had a dream. She saw that she was not at home but somewhere else, in a valley. She saw Prophet Mpanji standing on a top of a mountain and started to run to reach him. When she met him, the prophet told her that she was wearing her grandmother's face and that he would take it off. Then Asifiwe also saw it: she was not being herself. She had kind of a layer on her face and when the prophet removed it her face became her own again. ${ }^{42}$ Asifiwe is now a young widow. She has experienced being released from the spirits' realm and is attending the GMCL services three times per week and choir practices in addition. Once possessed herself, she is now a prayer servant helping others who suffer as she used to. Instead of losing consciousness and screaming and kicking in a spirit trance, she is now among the women who dress up for the healing prayers and pray for the women rolling on the mud floor. "If we had come earlier to Mpanji,"

40 "Nikafika mahali sasa, kwa nini nimeokoka halafu namjua Mungu, kwa nini sifanikiwi kwenye maisha yangu, kwa nini maisha yangu hivi?" (I then came to a place in my life, I asked why, I am born-again? I know God, why do I not succeed in my life? Why is my life like this?) Interview with Asifiwe, February 1oth 2014.

"Wewe sio wewe." Interview with Asifiwe, February 1oth 2014.

42 Interview with Asifiwe, February 10th 2014. On the relevance of dreams in African church contexts see Simon Charsley, "Dreams in African Churches," in Dreaming, Religion and Society in Africa ed. M.C. Jȩdrej and Rosalind Shaw (Leiden: Brill, 1992), 153-176. 
she says, "my husband would be alive." But it is probably easier to be a childless widow than a married woman without a child. "To be saved is more than being born-again," she says. "It also takes salvation of the soul." In the GMCL she has come to possess something she previously lacked.

Asifiwe's story illustrates the social shame and exclusion that comes with childlessness in a society that values family life and where a woman's primary role is to be a mother. As Boddy has argued, "a threat to women's fertility is a serious threat to their gendered sense of self." ${ }^{43}$ Asifiwe's narrative also interestingly demonstrates the lack of agency that is present in many of the illness narratives I heard from my research participants. Being attacked and possessed by the spirits is above all a loss of personhood and agency. Asifiwe was not allowed to keep her own face but wore the face of an old woman, one who had already passed away. A person is told apart from other people by her face and losing one's face is a strong metaphor for a lack of recognition. The face conveys emotions, speech, and expressions, and impacts on social acceptance. When Asifiwe explained her condition she said that she was someone who was not herself. She was not able to express herself normally, and when she spoke her sentences were meaningless. Her relatives rejected her. It was the life of an outcast. Wearing the face of an old woman transformed her into an unwanted person and altered her life plans. Like old women she was not able to give birth. As she lamented her childlessness, she asked God why she did not succeed and why her life was what it was. A similar pattern was present in many stories I was told: in dealings with the malicious spirits one is robbed of one's plans and dreams for life. One's personality is taken over together with one's abilities and used for someone else's profit. In stories of spirit possession the theme of exploitation came up regularly. The spirit possessed told me how their own economic situation worsened, while the spirits made them labor for someone else's benefit. Similar themes of loss of identity and exclusion from a life that is communally considered meaningful are widely documented in research on witchcraft. ${ }^{44}$

Academic discussions on personhood, self, and agency in African contexts have often revolved around the opposition of what is seen as Western individualism and an African understanding of personhood which is said to be embedded in relationships. ${ }^{45}$ The dichotomy has been challenged by Kaphawagani,

43 Boddy, "Spirit possession," 417.

44 Sónia Silva, "Political evil. Witchcraft from the point of view of the bewitched," in Evil in Africa. Encounters with the everyday, eds. William Olsen \& Walter van Beek (Indianapolis: Indiana University Press, 2015), 29-42.

45 See Ifeanyi Menkiti, "Person and Community in African Traditional Thought," in African Philosophy: An Introduction (Lanham: University Press of America, 1984), 171-182. 
who has pointed out that this kind of dualistic approach does no justice to the diversity of African discourses of personhood, ${ }^{46}$ wherein questions of autonomy and belonging are equally relevant. Nyamnjoh speaks of domesticated agency that "stresses negotiation, interconnectedness and harmony between individual interests and group expectations." ${ }^{\text {77 }}$ In African understandings of agency, the achievements and self-fulfillment of an individual are meaningless unless they are made communal. My research participants talked about agency when they explained how the spirits restrained them from achieving what they wanted to achieve. Their wish to be well again translated into regaining not only health but, with it, the abilities and power to achieve a meaningful life. By making their suffering and their yearning for a different life public and communal, the women in the GMCL were domesticating agency. Spirits made them objects, some even say slaves, and healing through communal prayers restored them as subjects. ${ }^{48}$

\section{Restoring Moral Agency}

Being made ill by the spirits was often linked with (in)fertility, and explanations for women's vulnerability to spirits were found in the female body, which attracts spirits as its reproductive organs - the womb and ovaries - are considered to contain a lot of blood, which is food for the spirits. Moreover, women's reproductive abilities are useful to the dark forces, since the reported sexual relationships between women and the spirits result in the birth of new generations of spirits, as the stories of Hekima and Sofia illustrate. But reasons for their greater susceptibility to possession were also found in their hearts and minds. I was told that women have a greater propensity to sin than men, as illustrated by the biblical story of Eve and the garden of Eden. ${ }^{49}$ This was explained to me by Nuru:

46 Didier Kaphawagani, “Some African conceptions of person. A critique," In African Philosophy as Cultural Inquiry, eds. Ivan Karp \& D.A. Masolo (Indianapolis: Indiana University Press, 2000), 66-79.

Francis B. Nyamnjoh, "Delusions of development and the enrichment of witchcraft discourses in Cameroon," in Magical Interpretations, Material Realities: Modernity, Witchcraft and the Occult in Postcolonial Africa, eds. Henrietta Moore \& Todd Sanders (London: Routledge, 2001), 31.

48 Ibid.

49 Interview with Pastor Lusungu and his wife Susan, July 16th 2013. 
Us women, we are easy in a different way than men which means we are weak, it means us women, we are created somehow weak. It also means that the spirits easily enter us, more than with men. I think that men, our partners, I do not know how God created them, this I do not understand yet, but us women, we have a sort of weakness. ${ }^{50}$

I was also told that women leave the door open to Satan and make way for his servants to enter. The link between sin and illness was thus clearly pronounced by many Christians in the GMCL, and illness has been associated with moral corruptness in many African societies. With regards the Nyakyusa, Wilson wrote, "there is a direct and immediate link between misfortune and wrongdoing." ${ }^{11}$ But instead of confessing one's sins and repenting, being diagnosed as spirit possessed frees the individual from the burden or suspicion of being morally corrupt, and, rather, transfers the blame to some other agent: the spirits, kinfolk, haters. Many of my informants spoke about the link between illness and sin but none of them explained their own illness in terms of personal moral failure. Being the prey of the spirits constituted them as victims, not as fallen. They were made innocent again. The logic of spirit possession in this context and in this community is that of exploitation. Someone else is profiting from one's suffering but the evil has its roots outside the suffering person. The evil is not distant but nor is it in oneself; rather, it is associated with kin and family. In these narratives spirit possession elevates mundane suffering, like alcoholism, infertility, and dropping out of school, and gives them purpose and explanation that is embedded in the social world, family, and kin. The moral agency of a person is restored and she is not subject to blame.

A turning point in these stories comes when the sick hear about Prophet Mpanji and come to him. Hardly anyone talks about coming to this community, but they speak explicitly about coming to the prophet, thereby making it clear that the GMCL is a community that gathers around the prophet's power to heal. The church is a place of diagnosis and the prophet has the ability to explain the root cause of the spirits' attacks. Coming to him marks the end of the worst of the suffering, although some problems may remain. Sofia explains:

$50 \quad$ Interview with Nuru, February 3 rd 2014. "Kwa hiryo wanawake sisi ni wepesi tofauti na wanaume, ina maana sisi udhaifu, ulikuwepo tokea enzi hizo, ina maana sisi wanawake tuliumbwa na udhaifu fulani. Ndiyo maana hata haya maroho ni rahisi kuingia kwetu, maana kwa mwanaume. Naona wanaume wenzetu, sijui Mungu aliwaumbaje, hapo ndiyo bado sijaelewa lakini, sisi wanawake kwa jumla tuna udhaifu fulani." 
"I got relief to a big percentage."52 Many experience healing despite the cure not being perfect. Many of those who came because of childlessness are still waiting and struggling with problems of infertility and the psychosocial pain and shame that come with it. Dramatic symptoms of trance, fainting, and seizures are still present. However, the treated stay in the church, continue to express gratitude and relief, and constantly come for prayers. I argue that this suggests an understanding of healing as a process where the cure is to some extent secondary; ${ }^{53}$ it is not so much about solving the problem as about having an explanation and recognition for one's affliction and struggle. In the stories of my research participants, the Christian community is a place for diagnoses but also a place for mourning one's loss and misfortune together with others. It is a community that restores hope; while one is still waiting for the perfect cure and solution, there is something meaningful to do and hope to cling to. As I argued earlier, spirit involvement comprises loss of agency and control over one's life. But is this community a place where women regain their agency? Or is it taken from the spirits and handed over to another master, Prophet Mpanji, who holds a pivotal role in diagnosing and thus explaining their lives?

Charismatic Christianity often places the "past" or "tradition" in strict opposition with what is seen as modernity, and presents itself as counterforce that brings progress by protecting people from the power of their past with the power of the Holy Spirit. ${ }^{54}$ The terms in which spirit possession is discussed and interpreted in the GMCL strongly suggests that the past holds one back and keeps one from a fulfilling and meaningful life. As the spirits are identified as deceased family members or representatives of the religious other, the GMCL becomes alternative kin that restores not only health, but also moral agency, and enhances belonging. Explanations given for spirit involvement thus discuss past, present, and morality in a powerful way.

$52 \quad$ "Nilipata nafuu kwa asilimia kubwa sana." Interview with Sofia, February 17 th 2014.

53 Candy Gunther Brown, "Introduction. Pentecostalism and Globalization of Illness and Healing," in Global Pentecostal and Charismatic Healing, ed. Candy Gunther Brown (Oxford, New York: Oxford University Press, 2011), 5 .

54 Rijk van Dijk, "Witchcraft and scepticism by proxy. Pentecostalism and laughter in urban Malawi," in Magical Interpretations, Material Realities. Modernity, Witchcraft and the Occult In Postcolonial Africa, ed. Henrietta Moore \& Todd Sanders (London, New York: Routledge, 2001), 103 . 


\section{References}

Auslander, Mark. “Open the Wombs!' Symbolic Politics of Modern Ngoni Witchfinding." In Modernity and Its Malcontents. Ritual and Power in Postcolonial Africa, edited by Jean Comaroff and John Comaroff, 167-192. London, Chicago: University of Chicago Press, 1993.

Behrend, Heike, and Ute Luig. "Introduction." In Spirit Possession. Modernity and Power in Africa, edited by Heike Behrend \& Ute Luig, xiii-xxii. Madison: Wisconsin University Press, 1999.

Boddy, Janice. "Spirit Possession Revisited: Beyond Instrumentality." Annual Review of Anthropology 23 (1994): 407-434.

Boddy, Janice. Wombs and Alien Spirits: Women, Men, and the Zār Cult in Northern Sudan. Madison: University of Wisconsin Press, 1989.

Brown, Candy Gunther. "Introduction. Pentecostalism and Globalization of Illness and Healing." In Global Pentecostal and Charismatic Healing, edited by Candy Gunther Brown, 3-26. Oxford, New York: Oxford University Press, 2011.

Charsley, Simon. "Dreams in African Churches." In Dreaming, Religion and Society in Africa, edited by M.C Jȩdrej and Rosalind Shaw. Leiden: Brill, 1992.

Gammelin, Lotta. "Health-seeking nomads and faith-healing in a medically pluralistic context in Mbeya, Tanzania." Mission Studies 35, no. 2 (2018): 245-264.

Gifford, Paul. Christianity, Development and Modernity in Africa. London: Hurst \& Company, 2015.

Gordon, David. Invisible Agents. Spirits in Central African History. Ohio: University Press, 2012. Kindle Edition.

Haar, Gerrie Ter. Spirit of Africa: The Healing Ministry of Archbishop Milingo of Zambia. London: Hurst, 1992.

Hasu, Päivi. "The Witch, the Zombie and the Power of Jesus: A Trinity of Spiritual Warfare in Tanzanian Pentecostalism." In Suomen Antropologi/Antropologi I Finland/ The Journal of the Finnish Anthropological Society 34, no. 1 (2009): 70-83.

Hinkkanen, Reea. Someone to Welcome You Home: Infertility, Medicines and the Sukuma-Nyamwezi. Helsinki: Rea Hinkkanen, 2009.

Kaphawagani, Didier. “Some African Conceptions of Person. A critique.” In African Philosophy as Cultural Inquiry, edited by Ivan Karp \& D.A. Masolo, 66-79. Indianapolis: Indiana University Press, 2000.

Lambek, Michael. Knowledge and Practice in Mayotte: Local Discourses of Islam, Sorcery, and Spirit Possession. Toronto: University of Toronto Press, 1993.

Lambek, Michael. "Rheumatic Irony: Questions of Agency and Self-deception As Refracted Through the Art of Living With Spirits." In Social Analysis: The International Journal of Social and Cultural Practice 47, no. 2 (2003): 40-59. 
Larsen, Kjersti. "Morality and the Rejection of Spirits. A Zanzibari Case." Social Anthropology 6, no. 1 (1998): 61-75.

Menkiti, Ifeanyi. "Person and Community in African Traditional Thought." In African Philosophy: An Introduction, edited by Richard A. Wright, 171-182. Lanham: University Press of America, 1984.

Meyer, Birgit. "'Make a Complete Break With the Past.' Memory and Post-Colonial Modernity in Ghanaian Pentecostalist Discourse." Journal of Religion in Africa 28, no. 3 (1998): 316-349.

Miguel, Edward. "Poverty and witch killings." Review of Economic Studies 72 (2005): $1153-1172$.

Nyamnjoh, Francis B. "Delusions of development and the enrichment of witchcraft discourses in Cameroon." In Magical Interpretations, Material Realities: Modernity, Witchcraft and the Occult in Postcolonial Africa, edited by Henrietta Moore \& Todd Sanders, 28-49. London: Routledge, 2001.

Salokoski, Märta. How Kings Are Made, How Kingship Changes: A Study of Rituals and Ritual Change in Pre-colonial and Colonial Owamboland, Namibia. Helsinki, Helsinki University Press, 2006.

Silva, Sónia. "Political evil. Witchcraft from the point of view of the bewitched." In Evil in Africa. Encounters with the Everyday, edited by William C. Olsen \& Walter E.A. Van Beek, 29-6o. Bloomington: Indiana University Press, 2015.

Vähäkangas, Auli. Christian Couples Coping with Childlessness. Narratives of Machame, Kilimanjaro. American Society of Missiology Monograph Series. Eugene, Oregon: Pickwick Publications, 2009.

van de Kamp, Linda. "Converting the Spirit Spouse: The Violent Transformation of the Pentecostal Female Body in Maputo, Mozambique." Ethnos:Journal of Anthropology 76, no. 4 (2011): 510-533.

van Dijk, Rik. "Witchcraft and Skepticism By Proxy: Pentecostalism and Laughter in Urban Malawi." In Magical Interpretations, Material Realities: Modernity, Witchcraft and the Occult in Postcolonial Africa, edited by Henrietta Moore \& Todd Sanders, 97-117. London: Routledge, 2001.

Wilson, Monica. Rituals of kinship among the Nyakyusa. London, New York: Oxford University Press, 1957. 